\title{
FROM THE EXPERIENCE OF APPLYING INNOVATIVE TECHNOLOGIES IN TEACHING SPEAKING SKILLS OF MEDICAL STUDENTS AT THE ENGLISH LANGUAGE LESSONS
}

\author{
CDjalilova N., ORCID: 0000-0003-2474-0137, Tashkent Pediatric Medical Institute, \\ Tashkent, Uzbekistan,nilufarxon_djalilova@mail.ru \\ CAkhmedova A., ORCID: 0000-0002-2141-1832, Tashkent Pediatric Medical Institute, \\ Tashkent, Uzbekistan
}

\section{ИЗ ОПЫТА ПРИМЕНЕНИЯ ИННОВАЦИОННЫХ ТЕХНОЛОГИЙ ПРИ ОБУЧЕНИИ НАВЫКАМ УСТНОЙ РЕЧИ СТУДЕНТОВ МЕДИКОВ НА ЗАНЯТИЯХ ПО АНГЛИЙСКОМУ ЯЗЫКУ}

\author{
(СДжсалилова Н. Д., 0000-0003-2474-0137, Ташкентский педиатрический медицинский \\ институт, г. Ташкент, Узбекистан, nilufarxon_djalilova@mail.ru \\ (CAxмедова A. Ф., ORCID: 0000-0002-2141-1832, Ташкентский педиатрический медииинский \\ институт, г. Ташкент, Узбекистан
}

Abstract. The article deals with the necessity and the importance of applying innovative technologies to foreign language lessons in teaching speaking skills. They have a number of advantages compared with other technology in the field of learning a foreign language, as they allow: to improve the process of organic combination of traditional forms and methods of education with innovation; implement training, information, games, modeling, design and analysis functions; general didactic perform such principles as the visibility, accessibility, difficulty feasible, system, transition from education to self-education, positive emotional background of training, between theory and practice.

Аннотащия. В статье рассматривается необходимость и важность применения инновационных технологий на уроках иностранного языка при обучении навыкам устной речи. Они имеют ряд преимуществ по сравнению с другими видами обучения в области изучения иностранного языка, поскольку они позволяют: улучшить процесс органичного сочетания традиционных форм и методов обучения с инновациями; реализовать функции обучения, информации, игр, моделирования, проектирования и анализа. В общей дидактике действуют такие принципы, как наглядность, доступность, достижимая сложность, система, переход от обучения к самообразованию, положительный эмоциональный фон обучения, между теорией и практикой.

Keywords: communicative activity of students', innovative technologies, speaking skills, problem-based learning.

Ключевые слова: коммуникативная активность студентов, инновационные технологии, разговорные навыки, проблемное обучение.

Today, when we can talk about Globalization, the demand for learning foreign languages is increasing. Globalization is a global process economic, political, cultural, religious integration and unification. The spread of English language is the main reason for accelerating the development of 
Globalization. Therefore, education in the field of foreign languages requires chops and changes. The main goal of training is the formation of communicative competence. Communicative competence - it is the ability and willingness to carry out interpersonal and intercultural communication with native speakers.

It is well known, people need a communication to know each other. It is a basic human activity, and basic of all human's communication is language. Language has some functions in people life, in everyday activities. People use language; they can introduce themselves, communicate with other, and enlarge their knowledge. Without language it is hard to imagine how people can cooperate and get along with other. In one of theory says that language is a means of communication among the nations and people, will be utilized to deliver someone's idea, felling,

In modern conditions, foreign language communication is becoming a significant component of the future professional activities of the specialist, in connection with this, the role of the discipline "Foreign Language" in non-linguistic universities is substantially increasing. Due to the requirements of the state educational standards of higher professional education, teachers should take into account professional specifics in the study of a foreign language, its focus on implementation the principle of professional orientation.

There are four skills in learning foreign languages: listening, speaking, reading and writing. Speaking is very important because speaking and human being cannot be separated from each other. Speaking is used to express their ideas and to communicate to people in civilized world. Speaking seems intuitively the most important skill to master. The success is measured in terms of the ability to carry out conversation in language speaking in an interactive process of constructing meaning that involves producing, receiving, and processing information.

Speaking is very important because by mastering speaking skill, people can carry out conversations with others, give the ideas and exchange the information with others. In speaking, students should master the elements of speaking, such as vocabularies, pronunciation, grammar, and fluency. While it is a bit of an exaggeration, students clearly feel that classroom-based speaking practice does not prepare them for the real world. As a foreign learner in Republic of Uzbekistan, many students have amount vocabularies and mastering the grammatical structure, but they still have difficulty in speaking. This problem also appears to the teachers of «Foreign languages» department of Tashkent Pediatric Medical Institute.

The students' difficulties occur when they speak English. This caused by students' limitation in mastering the component of speaking. Beside it, students practice speaking English rarely. They only have a little chance to practice speaking English out of class because most of their friends speak Uzbek or Russian languages. Students' speaking problem can be solved by giving a lot chance to them for practicing English either in the classroom or out of classroom. Practicing speaking English in the classroom should be interested with appropriate techniques in order to make students speaking skill can be improved and the process of learning can be enjoyable. These techniques can be used in teaching speaking.

This research is based on the important of speaking skills. Speaking was important to be learnt because speaking is the way to communicate with other people in order to deliver opinion and express idea, but in fact the students' ability in speaking English is low. It is caused by several factors such as there are some elements of speaking such as vocabulary, pronunciation, grammar and fluency that must be mastered by students in order to be good English speaker.

In this article, we used "Cluster", "Brain Storming", "Cinquain", "Jigsaw", "Insert" techniques to improve students' speaking skills. The main objective of this research is to describe the implementation of innovative technologies in teaching speaking and to identify how much 
students' speaking skills improvement after being taught by using "Cluster", "Brain Storming”, "Cinquain", "Jigsaw", "Insert" techniques.

Innovations in the educational process are a special type of innovative technologies that contain all the characteristics of social innovations. Of these, the most popular in the university are the flexibility of forms and the transition to a new level of organization of not only the educational process, but also the relations between all participants in the educational process. The organization of an innovative invariant of the educational process can be carried out within the framework of a problem-activity approach. Problem-based learning is a student-centered approach in which students learn about a subject by working in groups to solve an open-ended problem. This problem is what drives the motivation and the learning.

Thanks to innovative technologies, it is possible to engage students in interactive activities in English lessons, put each student in the center of the educational process, make him an active participant of teaching, organize his creative interaction with other students, give him the opportunity to realize himself as a person, to give the educational process a real practical orientation. A conscious and tangible practical result, a product, one way or another designed to solve a significant problem, taken from real life and which can be shared with others. The lesson should not be monotonous, methods and techniques have to contribute to enhancing initiative and creative expression.

Improving the effectiveness of teaching English is due to the skillful combination of various teaching methods and techniques. The use of some techniques from the technology of critical thinking in the educational process allows teachers to engage students in interactive activities in English lessons, to develop their creative potential so that they can apply their knowledge in later life and easily adapt to the outside world. Involved in the process of critical thinking, they independently acquire knowledge, put forward ideas together, use the acquired knowledge and skills in new situations in everyday life, create, learn to formulate their own opinions and ideas, and respect the opinions of others.

Among the techniques that are recommended for use in English classes to improve students' speaking skills are the following: "Cluster", "Brain Storming", "Cinquain", "Jigsaw", "Insert".

This study is classroom action research that was done in two cycles. The data collection was done using observation and test. The data from the observation that had been taken from every cycle analyzed descriptively while the data from test were analyzed quantitatively. The implementation of "Cluster", "Brain Storming", "Cinquain", "Jigsaw", "Insert" techniques in teaching speaking skills of medical students at the English language lessons at the Tashkent Pediatric Medical Institute was conducted in two cycles including cycle one and cycle two. The participants of this experience were 40 students. The result of this study shows that using innovative technologies can improve students' speaking skills. This was proven by students' test score that improved in every cycle. In the first cycle, the students' average score was 75.4 and in the second cycle students got 86.8 .

Let's consider these effective innovative technologies by more details:

The Sequin Method.

A sequin is a poem that requires the synthesis of information and material in short terms, which allows students to describe or reflect on any reason. The word "sequin" comes from French, meaning five. A sequin is a five-line poem.

Each student is given 10 minutes to write a sequin, then he will turn to his partner and they will make one of two sequins, with which both will agree. This makes it possible to critically examine this topic. This method requires that participants listen to each other and extract from the 
works of others those ideas that they can link with their own. Then the whole group will be able to get acquainted with the pair sequins. It allows forming further discussion.

Rule of creating sequin:

- In the first line, the topic is called in one word (usually a noun).

- The second line is a description of the topic in a nutshell (two adjectives).

- The third line is a description of the action under this topic in three words.

- The fourth line is a four-word phrases showing attitude to the topic.

- The last line is a one-word synonym that repeats the essence of the topic.

For example:

1) «It's a Wonderful planet we live on».

- Earth Earthquake.

- Beautiful, blue violent, destructive.

- Live, produce, pollute damage, destroy, break.

- Can be kind, can hurt may be awful.

- Planet disaster.

2) «Schools around the world». - School. - State, private. - Learn, participate, and attend. - A place where children learn - The process of learning.

Thus, sequins are a fast, but powerful tool for reflecting and summarizing concepts and information.

\section{- "Jigsaw” Method.}

Possibilities of use: when working with the given topic each student receives for development a subtopic. There is an exchange of information. Everyone listens to each other, asks questions, and makes notes, because this is the only way to get all the information.

- "Insert" Method.

This technique works at the stage of understanding and discussing the content.

I - interactive;

$\mathrm{N}$ - noting;

S - system;

E - effective;

$\mathrm{R}$ - reading;

$\mathrm{T}-$ thinking.

These are marking icons:

"V" - already knew;

"+" - new;

"-_" - thought differently;

"?" - I do not understand, there are questions.

While speaking, students can use notes, fill out a table in which the icons are the headings of the graph, information from the content is entered into the table abstractly.

"Insert" method is a method of active speaking, when the speaker stays alert and interested in the topic of communication. To keep this interest alive, we recommended our students to use three different colors of stickers and use stickers to demonstrate that they are 'familiar' or 'less familiar' with certain things from the given topic, or they 'wish to know more'.

Using this method we tested with 4 groups of 2 nd year students studying at the Tashkent Pediatric Medical Institute. To test the effectiveness of this experiment we asked 40 students to fill a short survey, and organized one focus group with 6 students. The survey included questions related to «Insert» method and its application and if the students followed the recommendations of the teachers and used stickers when speaking a topic. We also were interested if the students shared 
with their peers when they faced challenges or if they applied this method when preparing for other subjects. During the focus group we tried to understand if the attitudes of students changed to the given topic and the subject, and to what extent this method was useful in comparison with more traditional methods.

\section{- "Brain Storming” Method.}

This method is a simple technology for recording thoughts, ideas, and conversations. Recording is fast, associative. The theme is in the center. First comes the word, idea, thought. There is a stream of ideas, their number is unlimited, they are all fixed, students begins to speak them down from the top left and end right down. The method is an individual product of one person or one group. Expresses individual capabilities, creates a space for the manifestation of creative abilities,

The possibilities of use are diverse:

- in the systematization, repetition of the material;

- when working with the topic;

- when repeated at the beginning of the lesson;

- with the introduction to the topic;

- when collecting the necessary language material;

- under control.

For example:

-Date, Season, Week, Weekdays.

-Calendar, months.

-Holiday, year, numbers.

Through brainstorming, students call everything that they know and think on a topic, a sound issue. All ideas are accepted, regardless of whether they are correct or not. The role of the teacher is the role of the guide, which makes students think, while carefully listening to their thoughts,

- "Cluster" Method.

This method stimulates mental activity. Spontaneity freed from any censorship. It is graphic method of organizing the material. Thoughts are not piled up, but "piled up," that is, arranged in a certain order.

Compilation technology: recording words that spontaneously come to mind are written around the main word. They are circled and connected to the main word. Each new word forms a new core, which causes further associations. In this way, associative chains are created.

This method can be used.

- in the systematization of information obtained before acquaintance with the main source in the form of questions or headings of semantic blocks.

- at the stage of reflection. When checking acquired knowledge on the topic.

As language teachers, we have a tradition of integrating new media into our teaching. We have embraced any new technology, which was likely to improve learning. From the facts above, we give suggestions to the English teachers to use innovative technologies for effective oral communication. The most important feature of a classroom activity is to provide an authentic opportunity for the students to get individual meanings across and utilize every area of knowledge they have in the second or foreign language. They should have the opportunity and be encouraged to become flexible users of their knowledge, always keeping the communicate goal in mind.

Using innovative technologies in a classroom as a tool for language learning has many benefits. It gives stimulus to undertake the tasks. And could help in creating a long lasting impact on the learners. The role of teacher will change from an instructor's role to a coordinator. Self-paced 
independent learning methodology is what is being propagated with the help innovative technologies in English Language Teaching.

Thus, the innovative technologies that we reviewed today significantly enrich and diversify the teaching of foreign languages. In place of the monotonous work comes intelligent creative search, during which formed a new type of personality, active and purposeful, focused on constant self-education and development.

To sum up, we can say, that modern innovative technologies are a huge number of opportunities that lead to motivation as the main effective mechanism of human education and selfeducation, which is a reflection of the pedagogical credo of a modern teacher - "Desire is a thousand possibilities, reluctance is a thousand reasons ..."

\section{References:}

1. Mullamaa, K. (2010). ICT in Language Learning--Benefits and Methodological Implications. International education studies, 3(1), 38-44.

2. Nunan, D., \& Carter, R. (Eds.). (2001). The Cambridge guide to teaching English to speakers of other languages. Ernst Klett Sprachen.

3. Kunschak, C. (2004). Language variation in foreign language teaching: On the road to communicative competence. Lang.

4. Yang, W., \& Fang, F. (2008). Optimization of Multimedia English Teaching in Context Creation. International Education Studies, 1(4), 136-142. https://eric.ed.gov/?id=EJ1065458

5. Khujaniyazova, G. Yu. (2016). Innovative technologies and the teaching of foreign languages. Molodoi uchenyi, (12.4). 117-120. (in Russian).

\section{References:}

1. Mullamaa K. ICT in Language Learning--Benefits and Methodological Implications // International education studies. 2010. Vol. 3. №1. P. 38-44.

2. Nunan D., Carter R. (ed.). The Cambridge guide to teaching English to speakers of other languages. Ernst Klett Sprachen, 2001.

3. Kunschak C. Language variation in foreign language teaching: On the road to communicative competence. Lang, 2004.

4. Yang W., Fang F. Optimization of Multimedia English Teaching in Context Creation // International Education Studies. 2008. Vol. 1. №4. P. 136-142. https://eric.ed.gov/?id=EJ1065458

5. Хужаниязова Г. Ю. Innovative technologies and the teaching of foreign languages // Молодой ученый. 2016. №12.4. С. 117-120.

Работа поступила

в редакичию 05.03.2020 2.
Принята к публикации 12.03.2020 2.

Ссылка для цุитирования:

Djalilova N., Akhmedova A. From the Experience of Applying Innovative Technologies in Teaching Speaking Skills of Medical Students at the English Language Lessons // Бюллетень науки и практики. 2020. Т. 6. №4. С. 422-427. https://doi.org/10.33619/2414-2948/53/48

Cite as (APA):

Djalilova, N., \& Akhmedova, A. (2020). From the Experience of Applying Innovative Technologies in Teaching Speaking Skills of Medical Students at the English Language Lessons. Bulletin of Science and Practice, 6(4), 422-427. https://doi.org/10.33619/2414-2948/53/48 